\title{
AS DIMENSÕES DO DIREITO CONTEMPORÂNEO LUSO-BRASILEIRO E A CRISE MUNDIAL / THE DIMENSIONS OF CONTEMPORARY BRAZILIAN- PORTUGUESE LAW AND THE WORLD CRISIS
}

(Texto da conferência pronunciada pelo autor em 22 de abril de 2009 na Universidade do Minho, ao receber a "Cátedra Lloyd Braga”, maior distinção da entidade)

Ives Gandra da Silva Martins

\section{Resumo}

O presente artigo busca discutir que o século XXI deverá conhecer uma profunda revolução nos clássicos conceitos jurídicos, não só a partir de uma visão do direito constitucional à luz da soberania das nações, mas também do direito supranacional, que vai se universalizando pelo prisma da formação dos blocos regionais. Para o autor, assistimos o início de uma escalada que deverá desembocar, até o fim do século, num Estado Universal.

Palavras-chave: Revolução conceitual. Soberania. Direito supranacional. Blocos regionais de Estados. Estado Universal.

\begin{abstract}
This paper discusses that the twenty-first century will meet a profound revolution in the classical legal concepts, not only from a view of the constitutional right under the sovereignty of nations, but also of supranational law, which will universalizing through the prism of training regional blocs.

For the author, witnessed the beginning of an escalation that will culminate till the end of the century, in a Universal State.
\end{abstract}

Keywords: Conceptual revolution. Sovereignty. Supranational law. Regional blocs of States. Universal State. 
O século XXI deverá conhecer uma profunda revolução nos clássicos conceitos jurídicos, não só a partir de uma visão do direito constitucional à luz da soberania das nações, mas também do direito supranacional, que vai se universalizando pelo prisma da formação dos blocos regionais. Basta ter em mira o denominado "direito de ingerência", que as nações mais desenvolvidas, em nome de um pretendido consenso de representatividade do concerto das nações, outorgam-se para intervir pontualmente em outros países, como ocorreu, na década passada e na atual, no Iraque, Afeganistão, Kosovo, e Haiti, intervenções estas de maior visibilidade e repercussão.

A crise econômica mundial, que abalou o mundo em 2008 - cujos reflexos negativos ainda se fazem duramente sentir e deverão continuar a ser sentidos nos próximos trimestres, nos países desenvolvidos e também nos países emergentes -, serviu, apenas, para mostrar que a alavanca do desenvolvimento mundial, se não concorreu para facilitar a redução de tensões entre os povos e os países, servirá, de rigor e entretanto, para uma reflexão maior e conscientização quanto à necessidade de buscarmos soluções jurídicas, que transcendam às clássicas formulações do direito estável e nacional, do passado ${ }^{1}$.

É bem verdade que, após a $2^{\mathrm{a}}$. guerra mundial, os primeiros organismos supranacionais de atuação efetiva foram surgindo, como a ONU, com os órgãos a ela ligados FAO, UNESCO, etc.; o FMI; o Banco Mundial; a própria OCDE e, mais recentemente, com assunção das principais atribuições do GATT, a OMC; além do modelo europeu, hoje compaginando, na Comunidade, vinte e sete nações, dotado de pelo menos seis órgãos de administração jurídica além fronteiras, que servem de modelo para o mundo (Parlamento, Comissão, Conselho, Tribunal de Contas, Tribunal de Justiça e Banco Central). Por outro lado, formam-se blocos de menor expressão, como o MERCOSUL, o

\footnotetext{
${ }^{1}$ Hélène Tourard entende que este processo implica uma internacionalização das contribuições naturais e uma certa perda de soberania: "1176. L'internationalisation des constitutions montre qu'il existe des avancées au niveau des droits individuels mais que cela s'accompagne d'une perte de souveraineté pour les peuples. Dès lors, est-ce réellement plus démocratique ? L'internationalisation des constitutions porte atteinte à la souveraineté du peuple dans son expression originelle, c'est-à-dire dans le choix, par l'exercice du pouvoir constituant, d'un régime politique et des droits devant être garantis à tout membre de la société politique" continuando: "1178. L'internationalisation est une grande idée séduisante dans la mesure où elle impliquerait la victoire de la démocratie en tant qu'organisation des pouvoirs publics et comme garantie des droits de l'individu. La question reste ouverte de savoir si elle peut être mise en ceuvre sans répercussions sur les acquis des Lumiêres relatifs à la démocratie constitutionnelle. Sous réserve de certaines précautions, l'internationalisation pourrait être un moyen de développer un constitutionnalisme international par une universalisation du constitutionnalisme." (L'internationalisation des Constitutions Nationales, ed. LGDJ, Paris, 2000, p. 642/644).
} 
pacto Andino e outros grupos regionais, que começam a dar seus primeiros passos para abandonarem as características de mera zona de livre comércio e transformarem-se em autênticas uniões aduaneiras, objetivando um futuro mercado comum.

Estes primeiros passos, de extrema relevância, nos últimos sessenta anos, não representam senão o início de uma escalada que deverá, a meu ver, desembocar, até o fim do século, num Estado Universal, como defendi no livro escrito em 1977, O Estado de Direito e o Direito do Estado ${ }^{2}$.

Não desconheço, todavia, as dificuldades para que isto ocorra, decorrentes das diferenças do estágio de civilização em que se encontra cada país, de costumes, cultura, conflitos de natureza religiosa e social, nacionalismo predominante, e fanatismos, que levam ao radicalismo e ao terrorismo.

O certo é que estes problemas ai estão à espera de solução.

Quando da invasão da Europa pelos mouros, em 711, e que durou até 1492, quando foi batido o último reduto de Granada, não se vislumbrava, durante seus primeiros séculos, uma solução européia e não moura para a região invadida. O que vale dizer: sessenta anos de novas experiências convivenciais, de um comunitarismo universal, nada obstante os choques, inevitáveis em qualquer processo de implantação, é muito pouco tempo, na busca de novas alternativas para a integração da humanidade, na aldeia global em que o mundo se transformou ${ }^{3}$.

Thomas Friedman, em seu livro "O mundo é plano", demonstra, como o mundo se estreitou, na economia e no mercado de empregos, sendo hoje o custo/benefício, a

\footnotetext{
${ }^{2}$ Escrevi: "A longo prazo, o mundo deverá compreender que somos um planeta navegando, no espaço, em busca da sobrevivência de seu principal habitante, que é o homem. As guerras, se não o levarem à destruição, serão substituídas por uma guerra maior, que é a de fazer a população mundial não perecer.

Por esta razão, a longo prazo, a batalha da sobrevivência do homem apenas poderá ser cuidada com o estabelecimento de um Estado Universal.

O mundo não está, no presente, preparado para seu nascimento. As pioneiras sementes não conseguiram ainda passar de um estado embrionário, seja no plano político (Sociedade das Nações, ONU, OEA), seja no plano econômico (MEC, ALALC, etc.). Essas sementes, todavia, estão na essência da continuação do homem. Se o homem não encontrar um consenso universal para se auto-dirigir e teimar nas escaramuças dos regionalismos, estará fadado ao suicídio e a transformar a terra num inóspito planeta, nos próximos séculos.

Somente um Estado Universal poderá, num futuro distante, superar, o problema, com as nações atuais servindo de Estados Federados, à semelhança dos países federativos, e o Estado Universal representando o poder central" (O Estado de Direito e o Direito do Estado, Lex Editora, São Paulo, 2006, p. 73).

${ }^{3}$ Luis Cesar Ramos Pereira não reconhece nesta integração das nações e organismos internacionais perda de soberania, mas integração delas a um objetivo maior, em face da responsabilidade internacional dos Estados na formatação de uma nova realidade. Declarou: "A Responsabilidade internacional do Estado é como a força invisível que faz mover a bússola, dando o devido norte e direção, para o cumprimento correto das normas de caráter Internacional, com uma função reparadora essencial.” (Ensaio sobre a responsabilidade internacional do Estado e suas conseqüências no Direito Internacional - A saga da responsabilidade internacional do Estado, Ed. LTR, São Paulo, 2000, p. 390).
} 
alavanca permanente desta integração. Principalmente, na área de serviços ela permite que pessoas no mundo inteiro prestem serviços entre si, sem que os usuários tenham qualquer noção de quem os está prestando. Quantas declarações de imposto de renda, nos Estados Unidos, são feitas por competentes e menos onerosos especialistas indianos, que desconhecem os contribuintes - chegam-lhes os números, e não os nomes - e sem que os declarantes saibam quem as elaborou ${ }^{4}$.

O mundo, portanto, que tanto evolui nesta integração supranacional, com a conseqüente e necessária formulação jurídica, deverá ultrapassar novas barreiras, nos próximos noventa anos, ou seja, até o fim do século, aprendendo com a crise atual e aproveitando-a para melhorar os instrumentos de integração 5 .

Algumas das exigências regulatórias são universais e, embora timidamente adotadas, por variados motivos, inclusive a falta de pronta adesão dos países mais poderosos, deverão ser implementadas como condição de sobrevivência mundial.

As questões ambientais estão a exigir rápido entrosamento entre todas as nações principalmente os Estados Unidos, reticentes quanto ao Protocolo de Kyoto - visto que o aquecimento global, tal qual um câncer recém detectado e no início, se não for combatido com medidas urgentes, universais e mediante sanções efetivas, também de âmbito geral, poderá gerar, ainda nos próximos 50 anos, colapsos incomensuravelmente superiores aos impactos das crises econômicas, políticas ou das guerras regionais, que continuam a macular a evolução da humanidade.

A necessidade, neste campo, da implantação de regras jurídicas de preservação ambiental de caráter mundial deve suscitar o interesse das nações, principalmente após a deterioração, ano após ano, da qualidade de vida, o surgimento de tormentas e cataclismos

\footnotetext{
${ }^{4}$ Thomas Friedman, O mundo é plano, Ed. Objetiva, 2007 (Brasil), em Portugal editado pela Actual Editora.

5 Em meu livro "Desenvolvimento Econômico e Segurança Nacional - Teoria do limite crítico" (Ed. José Bushatsky, 1971) procuro mostrar como as crises auxiliam o mundo a crescer e a aprender. Nele lembro os grandes avanços tecnológicos que o mundo obteve durante as guerras, indesejáveis sempre, pois geradoras de crises de destruição, mas que permitem a evolução econômica (Japão e Alemanha reconstruíram-se mais rapidamente que a Inglaterra e França, assim como os Estados Unidos saíram da crise de 29, de rigor com o pleno emprego na $2^{\text {a }}$. guerra, algo que não conseguira nem com o "New Deal" do Presidente Roosevelt (de 33 a 39). À evidência, o Estado Universal levaria à eliminação das guerras, no máximo podendo ter que enfrentar insurreições regionais.
} 
naturais, das alterações incontroláveis do clima, com reflexo negativo em toda a produção agropecuária, como também na própria vida dos centros urbanos ${ }^{6}$.

As medidas são urgentes, todas as nações devendo se voltar para a questão, cuja regulação jurídica deve ser universal, com aprovação, pelo direito local de cada uma, do que for decidido no consenso das nações, como forma de preservação do meio-ambiente.

À evidência, as nações que têm um custo maior de preservação ambiental, principalmente se emergentes, deverão poder partilhá-lo com as nações mais desenvolvidas, mediante, por exemplo, um Fundo compensatório que permitiria um real combate às causas de degradação do meio ambiente.

Não creio que, de imediato, isto seja possível, visto que o câncer da deterioração ambiental, do aquecimento global, começa apenas a ser detectado. Mas, não tenho dúvidas: quando a gravidade da corrosão do meio ambiente for percebida por todos os povos do mundo, todos os países serão forçados a participar de uma solução global ${ }^{7}$.

\footnotetext{
${ }^{6}$ José Renato Nalini lembra que: "Não se pode afirmar que o planeta vai bem!

Em setembro de 2002, a respeitada National Geographic, ao referir-se à saúde do planeta, denominou o texto de Terra em Transe. As notícias não são as mais agradáveis. Em 2001, o buraco na camada de ozônio protetora da Terra já estava do tamanho da América do Norte! Cujo governo se recusa a assinar o Protocolo de Kyoto, com o objetivo modesto de uma pífia redução de $6 \%$ nas emissões durante os próximos anos.

$\mathrm{O}$ impacto da raça humana há 2 milhões de anos sobre o continente africano foi pequeno. Enquanto o homem foi aprimorando sua capacidade de aprender, com gradativo aumento do cérebro, foi também aperfeiçoando sua capacidade de destruir.

Hoje somos 6,2 bilhões de indivíduos, com crescimento de 80 milhões por ano. E o impacto humano sobre o meio ambiente é comparável ao exercido pelos vulcões ou pela movimentação das placas tectônicas.

Da combinação entre imagens de satélite e registros históricos resulta que mais da metade da superfície terrestre do planeta já é utilizada para plantações e pastagens ou está pavimentada. Daí resultam profundas alterações na atmosfera, no solo e nos oceanos. Já não existe lugar no globo que não tenha sentido a ação humana" (Ética ambiental, 2a. ed., Millennium Editora, Campinas-SP, 2003, p. XVI).

${ }^{7}$ Curt Trennepohl e Terence Trennepohl rememoram: "Ao contrário da Conferência de Estocolmo, em 1972, em que os blocos alinhados Norte/Sul e Leste! Oeste disputavam palmo a palmo a hegemonia política mundial e, por conseguinte, divergiam abertamente de quaisquer iniciativas que implicassem num envolvimento conjunto, mesmo por uma causa de extrema importância, na Cúpula do Rio a cooperação entre as nações prevaleceu sobre os conflitos ideológicos.

O resultado da Eco 92 foi muito além dos compromissos internacionais assumidos e assinados no evento. Mostrou que existe a possibilidade real de cooperação e de ações conjuntas entre todos os povos na busca de soluções para as questões ambientais que afetam a humanidade como um todo. Entre os acordos internacionais de parceria global, assinados na oportunidade, encontram-se a Declaração do Rio e a Agenda 21.
}

A Declaração do Rio sobre Meio Ambiente e Desenvolvimento proclamou 27 (vinte e sete) princípios, entre os quais se destaca o reconhecimento, pelos países desenvolvidos, da "responsabilidade que lhes cabe na busca internacional do desenvolvimento sustentável, tendo em vista as pressões exercidas por suas 


\section{Quaestio Iuris}

vol.04, nº1. ISSN 1516-0351

A urgência de uma regulação universal para a preservação do meio-ambiente além do tímido Protocolo de Kyoto, não é um único problema a exigir a conformação de um direito supranacional.

Outra questão que está a demandar regulação mundial mais precisa é a que envolve o comércio internacional, o mercado de capitais e o sistema financeiro.

A crise de 1929 permitiu o aperfeiçoamento dos mecanismos de controle das crises, com a multiplicação dos bancos centrais, em todo o mundo, assim como a criação e o fortalecimento do FMI, do Banco Mundial, da OMC e da OCDE, com variado elenco de medidas possíveis para solução de controvérsias ${ }^{8}$.

Os primeiro e segundo choques do petróleo, na década de 70, levaram as nações desenvolvidas ao retorno às soluções protecionistas, no comércio internacional, após a Rodada de Tókio, em 1979, concomitantemente à reunião da OPEP, que estabeleceu o aumento do preço do petróleo (Viena). Na época, tal comportamento contou com a tolerância do GATT, para com as nações desenvolvidas que o adotaram, a partir dos dois eventos. As nações emergentes, todavia, altamente endividadas ainda por decorrência do $1^{\circ}$ choque e dependendo do fortalecimento dos mercados externos, que se fecharam, despencaram. A década de 80 foi considerada uma década perdida, com inflação e

sociedades sobre o meio ambiente global e as tecnologias e recursos financeiros que controlam". Desta forma, concordaram que os Estados tem responsabilidades comuns, porém diferenciadas conforme seu estágio de desenvolvimento.

Mais ainda, convencionou-se que "os Estados devem cooperar na promoção de um sistema econômico internacional aberto e favorável, propício ao crescimento econômico e ao desenvolvimento sustentável em todos os países, de forma a possibilitar o tratamento mais adequado dos problemas da degradação ambiental". Por último, a Declaração do Rio consignou que "as autoridades nacionais devem procurar promover a internacionalização dos custos ambientais e o uso de instrumentos econômicos, tendo em vista a abordagem segundo a qual o poluidor deve, em princípio, arcar com o custo da poluição, com a devida atenção ao interesse público e sem provocar distorções no comércio e nos investimentos internacionais" (Licenciamento ambiental, $2^{a}$. ed., Ed. Impetus, Niterói-RJ, 2008, p. 7/8).

\footnotetext{
${ }^{8}$ Wilhelm Hofmeister lembra que: "o comércio internacional tem passado por um processo gradual, porém contínuo de institucionalização, inicialmente através do Acordo Geral sobre Tarifas e Comércio (GATT), de 1947 e posteriormente com a conclusão da Rodada Uruguai e a criação da Organização Mundial do Comércio (OMC) em 1994. Este aumento do grau de institucionalização representou também a jurisdicionalização do comércio internacional, e neste sentido, o aperfeiçoamento do sistema de solução de controvérsias instaurado com a OMC, tornou-se fundamental para que fosse estabelecida a necessária segurança jurídica na solução dos litígios surgidos no âmbito global das relações comerciais internacionais. Do mesmo modo, a formação de blocos econômicos regionais, de variada intensidade em seus níveis de integração, ocasionou o surgimento de diferentes sistemas de resolução de litígios inicialmente circunscritos a seus Estados membros. Por outro lado, a possibilidade de dois blocos regionais celebrarem entre si um acordo de livre comércio, acentua a superposição de distintos sistemas de solução de controvérsias, os quais podem apresentar eventuais incompatibilidades, tanto formais (processuais), quanto materiais (determinação da norma aplicável)" (Solução de controvérsias OMC, União Européia e Mercosul, ed. Fundação Konrad Adenauer/Instituto de Relações Internacionais/ECSA Brasil América Latina, Rio de Janeiro, 2004, p. 7/8).
} 
crescimento pífio para a maioria das nações, inclusive com a declaração das moratórias mexicana (82) e brasileira (86).

A moratória brasileira foi mais consistente, porque, não só continuou, o país, pagando os juros da dívida, como se comprometeu a pagar o principal em prazo certo. $\mathrm{O}$ Brasil, no curso daquela própria década e na seguinte, reduziu sua dependência externa a valores inexpressivos para a dimensão de sua economia, o que não ocorreu com a Argentina, ao decretar com a moratória do início do século XXI, cujos reflexos perduram até hoje.

O certo é que aquela crise e as posteriores, das décadas de 80 e 90, não afetaram as grandes economias. A queda do muro de Berlim e a globalização da economia permitiram que as nações emergentes se recuperassem, vencendo, inclusive, o fantasma da inflação, com crescimento superior ao das nações desenvolvidas.

Algumas nações emergentes ganharam especial destaque, entre elas o Brasil, a Índia, a China e a Rússia, após o colapso do império soviético?.

A crise de 2008, todavia, teve globalização semelhante à crise de 29, com a diferença de que os mecanismos de consulta e atuação conjunta das nações permitiram que seus efeitos, embora terrivelmente impactantes, fossem menores que os de 1929.

9 O Escritório Nacional de Estatística de Pequim divulgou em 14/01/09 o quadro do desenvolvimento dos países no ano de 2007. É o seguinte:

\section{O AVANÇO DO DRAGÃO}

China passa a Alemanha e se toma a terceira maior economia do mundo

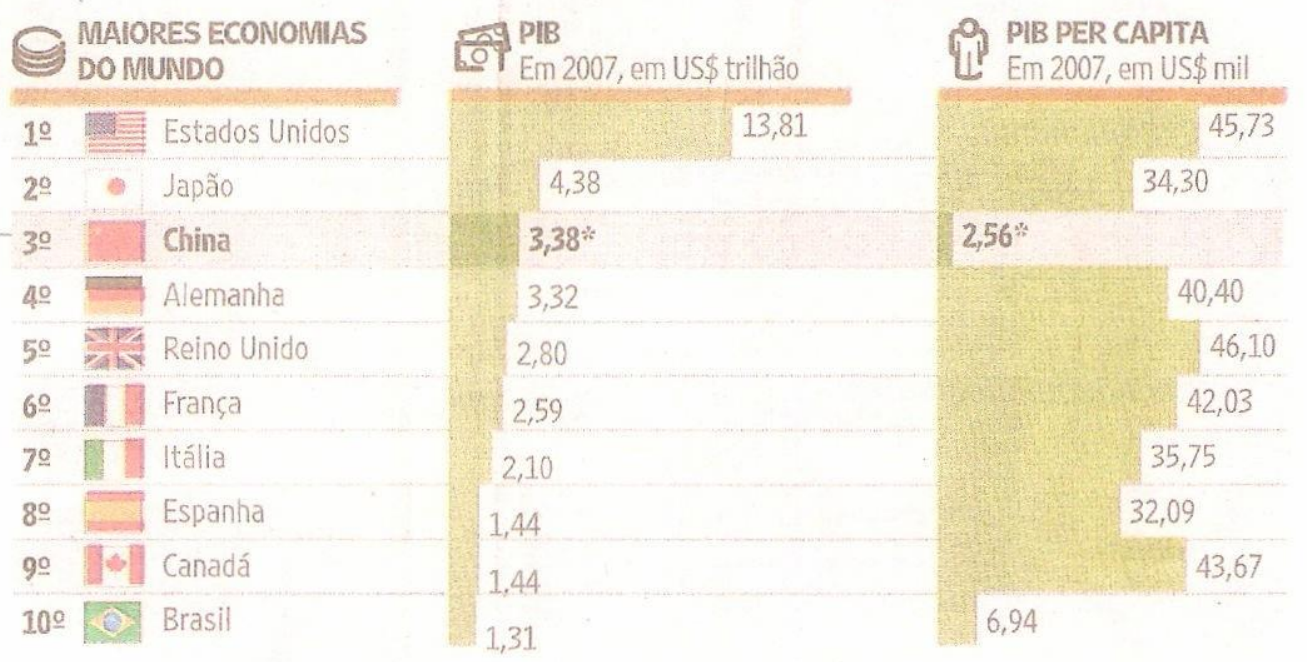

(Folha de São Paulo, 15/01/2009, Caderno Dinheiro, p. B8). 
O diferencial foi a maior resistência à recessão, nos países emergentes, que, a meu ver, por terem um padrão de vida menor que a das nações civilizadas, adaptaram-se melhor à nova realidade.

De qualquer forma, revelou-se que o mercado de capitais não encontrou ainda uma regulação capaz de evitar as grandes oscilações das bolsas e do sistema financeiro. Este último, mais preocupado com o aspecto formal dos créditos das instituições financeiras, descuidou-se da verificação de sua qualidade, sobre permitir uma multiplicação de operações no vazio, a ponto de se transformar num mercado virtual de papéis, sem lastro.

Creio que será mais fácil a correção do sistema financeiro, desde que o FMI e os bancos centrais do mundo inteiro se orientem para adoção de normas mais rígidas quanto a multiplicação da moeda virtual e um controle direto e eficiente na qualidade dos papéis em que se lastreia o sistema ${ }^{10}$.

Mais difícil será a operacionalidade do mercado de capitais, em que o jogo é inerente a sua existência e em que os operadores do mercado têm mais força que os governos.

Creio que seria desejável a adoção de regras também mais rígidas, no caso de oscilações, ocorrendo intervenção, por exemplo, sempre que os papéis experimentem, em um dia, oscilação superior a um determinado percentual não muito elevado, devendo ser retirados do mercado por período mais longo (1 ou 2 semanas), não como hoje, em que se suspende o prazo de negociação por um breve período. Dessa forma tornar-se-ia o jogo - que sempre existirá - um pouco mais controlável.

Estou convencido de que uma regra mundial de controle mais efetivo é necessária, sendo a aplicação de um direito supranacional nitidamente, mais abrangente, mais interventiva e mais universal.

O meio ambiente e o direcionamento de investimentos são dois campos em que a integração mundial, tornando o mundo menor, faz-se necessária. E a crise, certamente,

\footnotetext{
${ }^{10}$ Andrea Murta lembra que nos Estados Unidos: "Boa parte dos analistas continua cética quanto à eficácia das injeções de dinheiro em instituições financeiras. No último ano, o governo investiu ou emprestou aproximadamente US\$ 7,2 trilhões — cerca de metade do PIB dos EUA- para combater a crise financeira, mas a economia continua a se desacelerar", concluindo: "Bernanke também discutiu a necessidade de maior supervisão das instituições financeiras, desde que "não limite iniciativas inovadoras". O alvo principal da regulação, para o presidente do Fed, deve ser as empresas consideradas "grandes demais para falir", como as Imobiliárias Fannie Mae e Freddie Mac ou a super-seguradora AIG - que receberam bilhões do governo para evitar a bancarrota. Para ele, elas devem permitir supervisão mais profunda sob o nível de risco assumido" (Folha de São Paulo, 14/01/09, Caderno Dinheiro, p. B8).
} 


\section{Quaestio Iuris}

vol.04, nº1. ISSN 1516-0351

levará a soluções jurídicas universais mais abrangentes, entre elas, a de maior controle jurisdicional $^{11}$.

A questão da integração entre as nações será passo decisivo para a criação de um Estado Universal ou uma confederação de países, semelhantes à União Européia, de natureza global.

À evidência, tais problemas somente poderão ser superados com o diálogo à exaustão e jamais com represálias de idêntica violência. É o caso do islamismo, pluridividido, cujas correntes mais radicais ressuscitam lideranças do século VII e VIII do tempo da invasão da Europa -, sustentam que os poderes político e o religioso se confundem, e preconizam a eliminação daqueles que consideram infiéis, com atos de terrorismo espalhados por todo o mundo, no estilo de Bin Laden ${ }^{12}$.

Essa visão político-religiosa, para a qual o terrorismo é uma forma de atingir a vida eterna em grau de santidade, ao ponto de as "bombas-humanas" serem permanente

\footnotetext{
${ }^{11}$ Rui Manuel Moura Ramos, ao falar sobre o sistema jurídico comunitário europeu lembra que: "O sistema jurisdicional comunitário assentou desde a sua criação em dois eixos ou pilares estreitamente associados num conjunto integrado que exerce o poder judicial no quadro comunitário: a jurisdição comunitária propriamente dita e as jurisdições nacionais.

A associação das jurisdições nacionais a esta empresa impunha-se de toda a evidência. Se a construção comunitária implicava a criação de direitos e obrigações não apenas na esfera jurídica dos Estados-Membros mas também na dos seus nacionais e mesmo de outras pessoas jurídicas, a realização judiciária destes direitos não podia apenas ser confiada ao aparelho judicial directamente criado pelos Tratados. Daí que as jurisdições nacionais tivessem sido chamadas a colaborar nesta tarefa, tendo-lhes sido reconhecida competência para aplicar o direito comunitário. O que redunda, aliás, na extensão à administração da justiça da aplicação de um princípio que vale para toda a administração no sistema comunitário: o princípio da administração indirecta que faz com que este sistema se sirva, para a prossecução dos seus objectivos e para a realização das tarefas que lhe são confiadas, dos órgãos já estabelecidos no seio dos Estados. Se assim acontece para a administração em geral, a simples aplicação desta idéia à administração da justiça justificava que aos tribunais nacionais fosse reconhecido um papel relevante no sistema jurisdicional comunitário" (Temas de Integração - A União Européia - Os caminhos depois de Nice, $2^{\circ}$ semestre de 2001, $1^{\circ}$ semestre de 2002, n. 12 e 13, Ed. Almedina, Lisboa - Portugal, 2002, p. 84/85).
}

${ }^{12}$ Escrevi: "Tão logo Bush invadiu o Iraque, veiculei pela "Folha de São Paulo", o artigo "Terrorismo Oficial de Bush", em que prenunciava que o Iraque seria uma nova Vietnã para os americanos. É que estou convencido que o terrorismo político, arma dos mais fracos, não pode ser combatido como se combate o narcotráfico ou a criminalidade em geral.

O terrorismo político só pode ser combatido com o diálogo à exaustão, sem preconceitos, aceitando-se as diferenças culturais e nivelando-se o "status" do mais forte com o mais fraco, como Rui Barbosa prenunciou em Haia, ao defender a igualdade das nações independentemente de sua força.

O presidente Clinton obteve, em seu governo, um cessar fogo entre palestinos e israelenses mediante um diálogo permanente. É bem verdade que Arafat tinha mais sensibilidade que os radicais de Hamas, os quais, todavia, foram eleitos pelo povo. Do ponto de vista do Direito Internacional, a resposta de Israel é justificada, pois foi o grupo Hamas que deu início às hostilidades, mas o objetivo de Israel de destruir por completo o foco dos radicais de Hamas através reação desproporcional, que matou tantos inocentes quanto terroristas, parece-me de difícil consecução, pois o número de mortos palestinos termina por aumentar o ódio islâmico contra Israel.

Ódio gera ódio. Morte de inocentes de ambos os lados gera a vontade de vingança, com o que o drama do Oriente Próximo nunca terá fim. Creio que a pressão crescente da comunidade internacional e a necessidade de abertura de um diálogo à exaustão entre as partes em conflito, são as únicas tênues esperanças de que, um dia, teremos paz naquela conturbada região" (publicado no Portal Migalhas - 19/01/2009). 


\section{Quaestio Iuris}

vol.04, nº1. ISSN 1516-0351

instrumento de ataques inesperados, é um tipo de marginalidade que não pode ser combatida pelos métodos clássicos, utilizados contra marginais que pretendem conservar a própria vida. No fanatismo religioso, tal ataque à humanidade não-mulçumana, faz-se por convicção. Quando o terrorista está disposto a sacrificar a própria vida, é porque suas convicções são irremovíveis e age na certeza de que faz o certo e que Alá o protege, incentiva e lhe dará uma vida eterna de bem-aventuranças. Conter o terrorismo políticoreligioso em linha armada e ameaça de pressões, inclusive pena de morte, nada significa.

Tem havido, todavia, evolução nos próprios costumes dos países sujeitos à disciplina político-jurídica religiosa islâmica.

As mulheres, antes condenadas a secundário papel, hoje cursam Universidades e adquirem conhecimento e força que as levará, certamente, a conquistas semelhantes às obtidas pelas mulheres ocidentais nos séculos XIX e XX. Tal nivelação levará, no futuro, uma sociedade de homens a conviver, em igualdade de condições com as mulheres, como ocorre no Ocidente, e à compreensão, como no cristianismo, de que os dois planos (político e religioso) não se confundem, a não ser na busca de valores éticos, matéria em que não há imposição possível. O futuro Estado laico ${ }^{13}$ não será, necessariamente, ateu, mas um Estado em que convivem os que acreditam e os que não acreditam em Deus, procurando criar uma estrutura jurídico-política capaz de dar, como dizia Bentham, a maior felicidade possível ao maior número de pessoas ${ }^{14}$. Os focos de intolerância políticoreligiosa permanecem ainda, de rigor, no Tibete chinês, na Índia, no próximo Oriente, na Irlanda e na Inglaterra, Paquistão, Índia, mas estou convencido, nada obstante os incidentes mais graves que ocorrem ou possam ocorrer - como, recentemente, a questão palestina -, que até o fim do século clara ficará a sábia afirmação de Cristo, ao responder aos fariseus:

\footnotetext{
${ }^{13}$ Apesar de o Brasil ser um Estado Laico, o preâmbulo de sua Constituição, invoca a proteção divina: "Nós, representantes do povo brasileiro, reunidos em Assembléia Nacional Constituinte para instituir um Estado Democrático, destinado a assegurar o exercício dos direitos sociais e individuais, a liberdade, a segurança, o bem-estar, o desenvolvimento, a igualdade e a justiça como valores supremos de uma sociedade fraterna, pluralista e sem preconceitos, fundada na harmonia social e comprometida, na ordem interna e internacional, com a solução pacífica das controvérsias, promulgamos, sob a proteção de Deus, a seguinte CONSTITUIÇÃO DA REPÚBLICA FEDERATIVA DO BRASIL" (grifos meus).

14 Jeremy Bentham, em seu "Uma introdução aos princípios da moral e da legislação", ao falar no mínimo ético, escreve: "Para concluir esta parte, recapitulemos e precisemos a diferença existente entre a ética privada considerada como uma arte ou ciência, e aquele setor da jurisprudência que encerra a arte ou ciência da legislação.

A ética privada ensina como um homem pode dispor-se para empreender o caminho mais eficaz que o conduz à sua própria felicidade, e isto através dos meios que se oferecem por si mesmos. A arte da legislação — a qual pode ser considerada como um setor da ciência da jurisprudência - ensina como uma coletividade de pessoas, que integram uma comunidade, pode dispor-se a empreender o caminho que, no seu conjunto, conduz com maior eficácia à felicidade da sua unidade inteira, e isto através de motivos a serem aplicados pelo legislador” (coleção “Os pensadores”, vol. XXXIV, Ed. Abril Cultural, São Paulo, 1974, p. 74).
} 


\section{Quaestio Iuris}

vol.04, nº1. ISSN 1516-0351

Dai a Cesar o que é de Cesar e a Deus o que a Deus pertence. E a regulação jurídica internacional tenderá, a meu ver, a consagrar o princípio.

O problema da pobreza e das diferenças étnicas também permanece, no início do século, mas, num Estado universal, tenderão a merecer solução melhor. Muito se falou a respeito do holocausto, considerado crime contra a humanidade e contra um povo, em especial, uma das chagas na história da humanidade. Nos dias que correm, todavia, a denominada "purificação étnica" ocorre em diversas regiões da África, às vistas insensíveis da comunidade internacional, não interessada, ainda, em intervir no continente africano, como o fez na Europa e no Oriente próximo ${ }^{15}$.

Em outras palavras, a evolução cultural de todos os povos deverá permitir um diálogo mais sério pela sobrevivência da terra.

Ora, à medida e na rapidez que a evolução tecnológica torna a terra cada vez menor e os povos cada vez mais próximos, a busca de uma universalização semelhante à experiência vivida pela comunidade europeia impor-se-á à humanidade, talvez com a criação de uma efetiva confederação de nações, com organismos internacionais semelhantes aos da União Européia, mas com poder de atuação mais efetivo que a UE oferta. A integração de todas as nações, numa confederação desta espécie, exigirá vocação e convivência mais harmônica, em que o direito de ingerência ganhará outro perfil, mediante forças de segurança para a integração e a paz entre as nações.

\footnotetext{
${ }^{15}$ Celso Lafer, com ressalvas e desculpas nesta nota à menção a posições do autor do presente estudo, referindo-se ao holocausto, lembra decisão paradigmática da Suprema Corte do Brasil (H.C. 82.424-RS Caso Ellwanger): "Na sua discussão crítica do império do direito positivo e da teoria do "mínimo ético" que leva à afirmação que tudo que é jurídico é moral, mas nem tudo o que é moral é jurídico, Ives dá como exemplo da sua inverdade o que ocorreu na Alemanha de Hitler, "pois ter-se-ia de dar por moral toda a legislação do extermínio dos judeus nascida da veiculação formal correta, na Alemanha nazista" (Ives Gandra da Silvas Martins, op. cit., p. 43).

O papel do Direito Natural, na concepção do Direito de Ives Gandra da Silva Martins é, penso eu, o de promover uma contínua vinculação entre norma e valor e, portanto, uma permanente aproximação entre Direito e Moral. Como no caso por ele mencionado da Alemanha nazista, está muito ciente de que pode ocorrer a possibilidade de um dualismo entre o respeito à justiça e o respeito à lei, dualismo classicamente configurado no diálogo entre Antígona e Creonte na peça de Sófocles discutida com este objetivo por Aristóteles.

Neste texto em homenagem a Ives Gandra da Silva Martins, não me proponho tratar da dicotomia direito natural/direito positivo e das suas funções, que é um tema recorrente da multissecular reflexão jusfilosófica sobre o Direito. O que me proponho é examinar um caso - o caso Ellwanger - decidido recentemente pelo Supremo Tribunal Federal. No julgamento do Habeas Corpus n 82.424/RS não só não ocorreu um dualismo entre justiça e lei, mas também se tratou do significado da legislação anti-semita da Alemanha nazista e da omissão do judiciário alemão. Esta omissão é um exemplo do que pode ocorrer quando não há correlação entre Direito e Moral, advogada por Ives Gandra da Silva Martins.

Como apontou o ministro Maurício Corrêa no seu voto: "as grandes catástrofes da história só se tomaram tristes realidades diante do silêncio daqueles que tinham o dever de reagir, e não o fizeram" (Supremo Tribunal Federal, Crime de racismo e antisemitismo - Um julgamento histórico do STF (Habeas Corpus n 82. 424/RS), Brasília, Brasília Jurídica, 2004, p. 40)" (Princípios Constitucionais Fundamentais, estudos em homenagem ao Prof. Ives Gandra Martins, Lex Editora, São Paulo, p. 277/278).
} 
Ganhará, pois, especial relevância uma confederação forte e convivencial, com forças armadas avançadas modernamente equipadas, para intervir com eficácia e eficiência em qualquer parte da confederação.

A ONU, pois, seria substituída por uma autêntica confederação de países, com uma autonomia quase soberana, ou uma soberania com ares de autonomia, vinculadas, todas as nações, a um poder central, como ocorre, nas Federações, com os Estados, Províncias ou Cantões, que possuem autonomia vinculada a um governo centralizador.

O princípio da solidariedade universal a ser juridicizado é a única forma, que, no tempo, permitirá a superação de questões de desinteligências e desintegrações, o que implicará, necessariamente, aceitação da maneira de ser de cada povo e de cada cultura, com seus valores preservados ${ }^{16}$.

Ódio gera ódio. Contra o terrorismo não profissional, mas por convicção, a arma não é adotar reação idêntica. O diálogo é a única forma. Lembro-me de um conto russo que li, quando menino, de sete cavaleiros invencíveis, que um dia se reuniram para comemorar sua invencibilidade. Surgiu, todavia, um cavaleiro andante para desafiá-los. De um só golpe um dos sete invencíveis dividiu-o, mas, para sua surpresa, do cavaleiro cortado ao meio surgiram dois, que, também divididos de um só golpe, transformaram-se em quatro. Todos os cavaleiros invencíveis decidiram, então, combater os quatro, que foram se multiplicando a cada divisão até que, após sete dias de lutas, os sete cavaleiros invencíveis foram derrotados pela multiplicação de cavaleiros andantes nascidos de cada derrota individual.

Temo que a luta armada contra o terrorismo derivado do fanatismo possa levar a uma multiplicação idêntica. Temo que Israel não esteja percebendo que, estando cercado de islâmicos por todos os lados, a única solução possível é o diálogo à exaustão para

\footnotetext{
${ }^{16}$ Manoel Gonçalves Ferreira Filho não acredita no Estado Universal, mas sim numa dezena de Comunidades: "A IMPROBABILIDADE DO ESTADO UNIVERSAL: Uma objeção certamente já veio à mente de todos. Por que os Estados-nação cederiam lugar a uma pluralidade de "Comunidades" e não a um "Estado universal"? Este não teria na ONU o seu esboço?

A meu ver, apesar da falada globalização, o mundo contemporâneo não está maduro para tal unificação. Falta um substrato sócio-histórico-cultural para tanto.

Os Estados atuais vinculam-se a grandes "culturas" ou "civilizações" ("ocidental" — com pelo menos três variantes, a anglo-saxônica, a latina e a bizantina, e a "oriental" - islâmica, budista, confucionista), em cujo cerne estão diferentes crenças religiosas, diferentes "filosofias" de vida, diferentes maneiras de conceber a vida e o mundo, o que se reflete numa diversidade de práticas, de usos e de costumes. Ora, como demonstrou o fracasso de políticas colonialistas, difícil é estabelecer o convívio pacífico dessas culturas debaixo de um mesmo poder", acrescentando: "Mais provável é servirem essas culturas de critério de aglutinação para as referidas "Comunidades". Conseqüentemente, o futuro veria em lugar dos quase duzentos Estados hoje existentes cerca de uma dezena de "Comunidades"” (O Estado do futuro, Ed. Pioneira, coordenação Ives Gandra Martins, São Paulo, 1998, p. 107).
} 
aprenderem a conviver. Estou convencido de que, até o fim do século, a questão será solucionada, mas, até lá, enquanto para cada ação houver idêntica reação, teremos muita instabilidade, dor e sofrimento.

A estes problemas acrescentar-se-á o fantasma do desemprego, originado por crises e pela substituição do homem pela máquina. Nenhuma legislação nacional consegue equacioná-lo, pois o emprego é determinado pelo mercado e a competitividade termina por ter no fator preço elemento relevante. Como a máquina não faz greve, não tem direitos, não tira férias e trabalha sem reclamar, o desemprego crescerá. Um Estado Universal poderá melhor regular a oferta de emprego e instituir uma única legislação laboral ${ }^{17}$.

Creio numa confederação mundial até o fim do século mais forte que a União Européia e com mais poder de intervenção para conduzir a humanidade, com todos os povos sendo representados no Parlamento global e nos órgãos diretivos da instituição política máxima, com regulação supra-constitucional.

O gênio de Gene Rodenberry, em seu "Jornadas nas Estrelas”, criou uma federação que rendeu a edição de mais de setecentos episódios e dez filmes de longa metragem. Como regra primeira imposta aos comandantes das naves interestrelares estava a de não intervir na maneira de ser de cada povo, buscando sua integração à federação, em todas as galáxias, com respeito a seus costumes ${ }^{18}$.

Creio que o mundo, que avançou tecnologicamente com as especulações de ficção científica de um Verne, de um Da Vinci, de um Wells ${ }^{19}$, poderá muito aprender com este gênio da ficção científica do cinema. Estou convencido de que, como os sonhos verneanos Júlio Verne (Vinte mil léguas submarinas; Robur, o conquistador; O castelo dos Carpatos); Leonardo Da Vinci com os projetos dos aparelhos de vôo e George Wells com A guerra dos mundos e a A máquina do tempo foram se transformando em realidade, assim também, um dia, uma confederação dos países permitirá o surgimento de um Estado universal onde, com maior facilidade, se eliminarão os conflitos. Não, no ideal Kantiano de uma paz

\footnotetext{
${ }^{17}$ Já Ernane Galvêas lembrava, no século passado, que: “O problema crucial da primeira metade do século XXI será o desemprego, o desemprego em massa.

Atualmente, o desemprego é baixo no Japão e nos Estados Unidos, entre 3\% e 5\% da população economicamente ativa, e alto na Europa e na América Latina, onde ultrapassa o nível de 10\%. Além de alto, o desemprego tem caráter endêmico na Índia, no Paquistão e nos países árabes. Na África, o problema do desemprego é insolúvel, devido às elevadas taxas de crescimento demográfico e ao enorme atraso cultural. O desemprego vai aumentar no mundo todo. Nos Estados Unidos, a tendência é de atingir cerca de $10 \%$, entre as populações negra e hispânica. Na Europa e na América Latina vai caminhar para 20\%, podendo chegar a 30\%" (O Estado do futuro, ob. cit. p. 128).

${ }^{18}$ Foram 5 séries (Startrek, The Next Generation, Deep Space Nine, Voyager e Enterprise).
} 


\section{Quaestio Iuris}

vol.04, nº1. ISSN 1516-0351

perpétua, através da democracia, mas de uma integração de todos os povos, num regime jurídico universal e abrangente, que respeite a maneira de ser de cada povo ${ }^{19}$.

E, neste particular, a maneira de ser da civilização lusíada, em que a integração foi sempre o elemento de maior presença, poderá servir de exemplo. Haja vista que, em idêntico espaço americano, conseguiu manter um país único, com variadas formas de cultura, ao contrário da América Espanhola, que se pulverizou em um número enorme de nações. E a prova maior reside numa integração consideravelmente mais relevante entre as diversas raças no Brasil do que em outras nações, ao ponto de todas as culturas que se somaram posteriormente à portuguesa lá conviverem em perfeita harmonia, inclusive judeus e muçulmanos, que, muitas vezes, reúnem-se em cerimônias comuns, numa demonstração de que culturas diferentes podem viver harmonicamente.

Adriano Moreira, no $1^{\circ}$ Congresso das Comunidades de Língua Portuguesa, em 1964, afirmou que há uma maneira de ser diferente do português, na sua presença no mundo. E esta maneira de ser, que permitiu a criação de uma nação continental, é aquela que, talvez, possa servir de exemplo para o mundo futuro, na conformação de um Estado Universal lastreado na solidariedade entre os $\operatorname{povos}^{20}$.

${ }^{19}$ Soraya Nour, em seu "À paz perpétua de Kant", busca mostrar a atualidade do pensamento do filósofo alemão. Na apresentação de seu livro o Embaixador Carlos Henrique Cardim lembra que: "Immanuel Kant, há dois séculos, expôs em seu texto intitulado A paz perpétua - um projeto filosófico a hipótese de que os Estados republicanos conviveriam sem guerras com outras repúblicas. O filósofo de Konigsberg utilizava o vocábulo República para designar os regimes políticos que, atualmente, poderiam ser denominados democráticos.

A discussão de uma suposta ausência de conflitos bélicos entre democracias, que desde a década de 80 ficou conhecida, no meio acadêmico, como "paz democrática", está hoje entre as mais relevantes questões a serem debatidas nas relações internacionais e na teoria da democracia. Nos Estados Unidos e na Europa, presentemente, esse é um dos grandes temas de institutos de pesquisa acadêmica e da agenda da política externa.

O debate do conceito de "paz democrática", nos moldes da hipótese kantiana, merece hoje atenção por três principais motivos: 1) muitos governos têm colocado atualmente a promoção da democracia como um ponto destacado de suas agendas de política externa, dando inclusive consequiência prática a essa proposta por meio de ações de assistência econômica e apoio político a países em fase de transição democrática, e até impondo sanções contra governos considerados "antidemocráticos"; 2) vários cientistas políticos sublinham hoje os efeitos da emulação produzida em outros países ainda em fase prédemocrática pelos regimes democráticos, gerando um verdadeiro processo de contágio crescente; e 3) a existência, nas mais importantes entidades regionais (União Européia, Mercosul, Nafta e Otan), da denominada "cláusula democrática", ou seja, o requisito obrigatório de os países-membros ou candidatos a membro seguirem em suas Constituições os ditames do regime democrático" (À paz perpétua de Kant, Ed. Martins Fontes, São Paulo, 2004, p. $\mathrm{XIII/XIV).}$

${ }^{20}$ No $1^{\circ}$ Congresso da Comunidades Portuguesas realizado em Lisboa (dezembro de 1964), na sede da Sociedade de Geografia de Lisboa, Adriano Moreira fundou inclusive a Academia Internacional de Cultura Portuguesa, cuja sede é na própria Sociedade de Geografia de Lisboa, a qual ocupa a secretaria perpétua. O ideal do sodalício é exatamente levar esta maneira de ser da cultura portuguesa de integração e solidariedade a todos os povos. 